TWO-STAGE, CLOSE COUPLED

CATALYTIC LIQUEFACTION OF COAL

SIXTH QUARTERLY REPORT FOR THE PERIOD

1 JANUARY 1990 - 31 MARCH 1990
A.G. COMOLLI
E.S. JOHANSON
S.V. PANVELKER
G.A. POPPER
T.O. SMITH

WORK PERFORMED UNDER CONTRACT

DE-AC22-88PC88818

HYDROCARBON RESEARCH, INC.

100 OVERLOOK CENTER, SUITE 400

PRINCETON, NEW JERSEY 08540

Recoi:..:

SEPTEMBER 1990 
TWO-STAGE, CLOSE COUPLED

CATALYTIC LIQUEFACTION OF COAL

SIXTH QUARTERLY REPORT FOR THE PERIOD

1 JANUARY 1990 - 31 MARCH 1990
A.G. COMOLLI
E.S. JOHANSON
S.V. PANVELKER
G.A. POPPER
T.O. SMITH

WO iK PERFORMED UNDER CONTRACT

DE-AC22-88PC88818

HYDROCARBON RESEARCH, INC.

100 OVERLOOK CENTER, SUITE 400

PRINCETON, NEW JERSEY 08540 


\title{
PRINTED IN THE UNITED STATES OF AMERICA
}

\author{
AVAILABLE FROM: \\ National Technical Information Center \\ U. S. Department of Energy \\ 5285 Port Royal Road \\ Springfield, Virginia 22161
}

This report was prepared as an account of work sponsored by the United States Government. Neither the United States nor the United States Department of Energy, nor any of their employees, makes any warranty, expressed or implied, or assumes any legal liability or responsibility for the accuracy, completeness, or usefulness of any information, apparatus, product, or process disclosed, or represents that its use would not infringe privately owned rights. Reference herein to any specific commercial product, process, or service by trade name, mark, manufacturer, or otherwise, does not necessarily constitute or imply its endorsement, recommendations, or favoring by the United States Government or any agency thereof. The views and opinions of authors expressed herein do not necessarily state or reflect those of the United States Government or any agency thereof.

This technical report is being transmitted in advance of DOE patent clearance and not further dissemination or publication shall be made of the report without prior approval of the DOE Patent Counsel. 


\section{TABLE OF CONTENTS}

ABSTP ${ }^{\wedge} \mathrm{CT}$

SUMMARY

INTRODUCTION

TASK 2 -MICROAUTOCLAVE STUDIES …........................................... 4

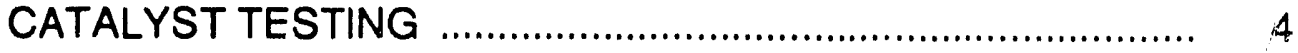

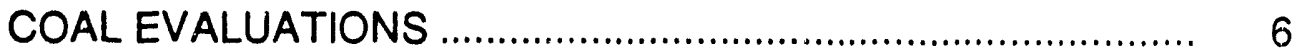

TASK 3 -BENCH SCALE STUDIES …............................................ 7

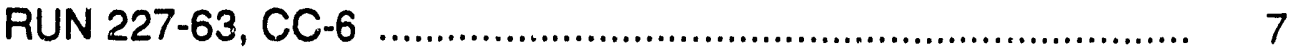

OBJECTIVES AND SCOPE OF WORK …............................... 7

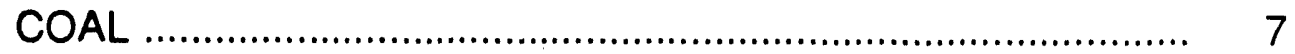

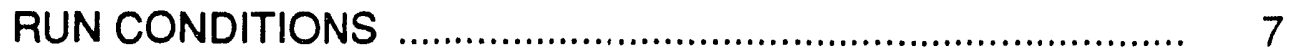

PERFORMANCE AND RESULTS …..................................... 8

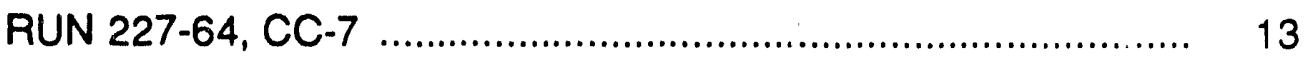

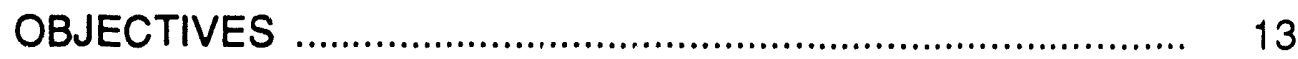

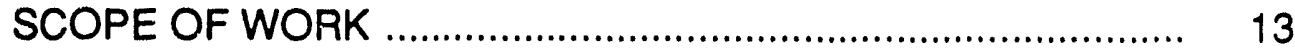

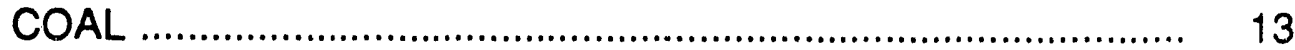

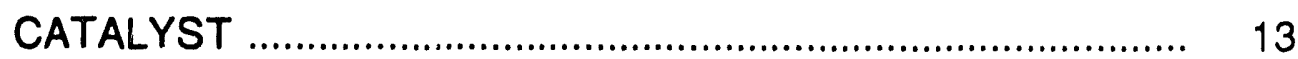

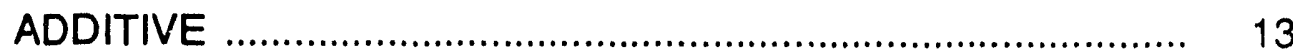

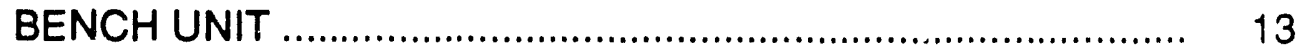

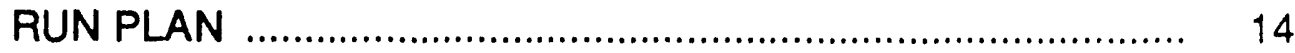

PERFORMANCE AND RESULTS ….................................... 14

RESULTS AND CONCLUSIONS, CC-7 …............................. 15

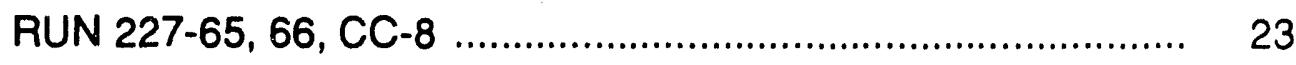

OBJECTIVES AND SCOPE OF WORK …............................ 23

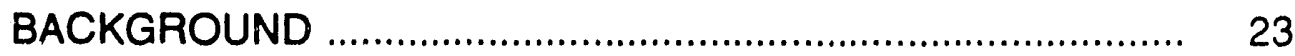

SLURRY DRYING PROCEDURE …................................... 23

PRELIMINARY WATER SLURRY DRYING TESTS ................ 24

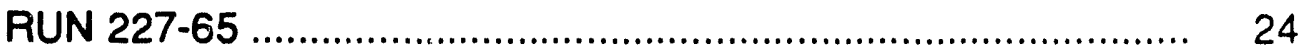

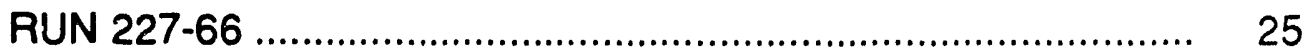

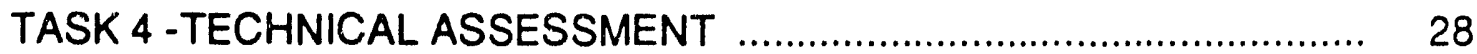

TASK 6 -ADMINISTRATION, REPORTING AND SAMPLE

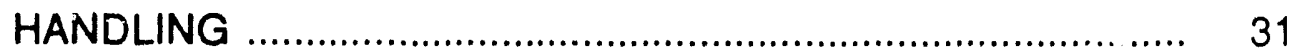




\section{LIST OF TABLES}

TABLE

TITLE

PAGE

1 "EED COAL ANALYSES FOR RUN 227-33 (CC-6)

RUN 227-63 FEED: ILLINOIS NO. 6 BUIZNING STAR MINE ... 9

2 RUN 227-63 OPERATING SUMMAFY

BENCH-SCALE TWO STAGE COAL LIQUEFACTION ............. 10

3 CTSL PERFORMANCE OF OIL

AGGLOMERATED CLEANED ILLINOIS NO. 6 COAL

BENCH-SCALE TWO STAGE COAL LIQUEFACTION

4 RUN PLAN C.C-7

5 FEED COAL ANALYSES CC-7 17

6 ANALYSES OF CHARGED CATALYST CC-7 ........................... 18

$7 \quad$ ANALYSES OF ADDITIVES CC-7 .......................................... 19

8 SUMMARY OF RESULTS CC-7 …………………................ 20

$9 \quad$ ANALYSES OF PRODUCTS CC-7 ………………................ 21

10 COMPARISON BETWEEN CATALYTIC/CATALYTIC

AND CATALYTIC/THERMAL

11 FEED COAL ANALYSES FOR RUN 227-66 (CC-8)

RUN 227-66 FEED: OTISCA PROCESSED

ILLINOIS NO. 6 COAL

12 ECCNOMICS OF CTSL PROCESSING OF WYOMING SUB-BITUMINOUS COAL

13 CTSL PROCESSING OF WYOMING SUB-BITUMINOUS COAL ECONOMIC ANALYSIS 


\begin{abstract}
This quarterly report covers activities in the Two-Stage, Close-Coupled Catalytic Liquefaction of Coal program in the period Jan. 1 - March 31, 1990, at Hydrocarbon Research, Inc.

Microautoclave studies on liquids and catalysts from Bench-Scale operations, alternate supported and dispersed catalysts and new coals were coriducted, results are summarized herein.

Results from Bench-Scale Runs CC-6 (cleaned agglomerated Illinois \#6 coal, CC-7, Dispersed Catalyst/Supported Catalyst Two-Stage and Reversed Sequential Operations and preliminary comments on CC-8, Evaluation of OTISCA coal are presented. Updated Wyoming coal economics and a current 1990 schedule are included.
\end{abstract}




\section{SUMMARY}

During the first quarter of 1990 , work was carried out in the microautoclave, microreactor, and Bench-Scale units. An economics analysis on sub-bituminous coal processing at two space velocities was also completed.

Several supported catalysts and a sample of iron oxide were screened in the microautoclave unsulfided and sulfided with DMDS and TNPS. A second shipment of Black Thunder coal from Wilsonville, oil agglomerated cleaned Illinois \#6 coal from Homer City, OTISCA cleaned coal and a New Mexico coal were evaluated for relative conversions with and without catalyst.

Results of Bunch-Scale developments with cleaned, oil agglomerated, Illinois \#6 coal from Homer City (CC-6), Dispersed Catalyst/Supported Catalyst Two-Stage and reversed sequential operation (CC-7), on Black Thunder Coal (CC-7), and preliminary observations on OTISCA cleaned coal are presented. The oil agglomerated cleaned coal gave higher conversion and distillate production than the OTISCA cleaned coal. The Dispersed/Supported Two-Stage operation yielded higher gas production than the reverse sequence but also showed the higher coal conversion.

Economic analysis of sub-bituminous coal processing at two space velocities showed a $3 \%$ higher return on investment with a $50 \%$ increase in space velocity. 


\section{INTRODUCTION}

The studies conducted in this the sixth quarterly report of Contract No. DE-AC22-88PC88818 are reported by task and in sequence other than the experimental modelling tests which are reported under Task 2 - Laboratory Studies.

Task 1 is the Management Plan and is complete. Task 2 is for Laboratory Studies and includes microautoclave and microreactor work. Task 3 is for Bench-Scale studies and in this report covers results of Runs CC-6, 7 and 8 . Task 4 is for Mini PDU Scale-up. Task 5 is the Technical Assessment, including Modelling and Economics. Task 6 is Administration. 


\section{IASK 2 - MICROAUTOCLAVE STUDIES}

During tho first quarter of 1990 the following programs were carried out in the microautoclave:

\section{CATALYST TESTING}

The microautoclave testing of presulfided catalysts was continued. This program compared the performance of catalysts that had been presulfided in a fixed bed similarly to the procedure used prior to CTSL Bench unit operations using DMDS (Dimethyl Disulfide) or TNPS (di-tertiary nonyl polysulfide) in gas oil, with catalysts presulfided in the microautoclave using these sulfiding agents in tetralin.

The alternative catalysts that were tested previously in the microautoclave as-received, without presulfiding, were presulfided in the microautoclave with DMDS/tetralin;

$$
\begin{aligned}
& \text { HRI } 5675 \text { UOP RCM-1-121 Nickel-Moly, Macropores } \\
& \text { HRI } 5676 \text { UOP RCM-1-122 Nickel-Moly, Micropores } \\
& \text { HRI } 5677 \text { UOP RCM-1-123 Iron-M )ly, Macropores }
\end{aligned}
$$

The following table summarizes the residual oil conversions obtained with these

\begin{tabular}{|c|c|c|c|}
\hline \multirow[b]{2}{*}{ Catalyst } & \multicolumn{2}{|c|}{$975^{\circ} \mathrm{F}+$ Conversion, $\mathrm{W} \%$} & \multirow[b]{2}{*}{ Pres!:Ifiding } \\
\hline & Unpresulfided & Presulfided & \\
\hline $\begin{array}{l}\text { Shell S-317 } \\
\text { Shell S-317 } \\
\text { Shell S-317 } \\
\text { Shell S-317 }\end{array}$ & $\begin{array}{l}22 \\
22 \\
22 \\
22\end{array}$ & $\begin{array}{l}28 \\
41 \\
45 \\
54\end{array}$ & $\begin{array}{l}\text { DMDS/gas oil } \\
\text { TNPS/gas oil } \\
\text { DMDS/tetralin } \\
\text { TNPS/tetralin }\end{array}$ \\
\hline $\begin{array}{l}5675 \text { Ni-Mo Macro } \\
5676 \text { Ni-Mo Micro } \\
5677 \text { F€-Mo Macro }\end{array}$ & $\begin{array}{l}18 \\
21 \\
21\end{array}$ & $\begin{array}{c}29 \\
52 \\
46,47\end{array}$ & $\begin{array}{l}\text { DMDS/tetralin } \\
\text { DMDS/tetralin } \\
\text { DMDS/tetralin }\end{array}$ \\
\hline
\end{tabular}
catalysts and Shell S-317 catalyst in the microautoclave using CTSL Bench Unit Filtered Liquid Product in 30 minute tests, at $825^{\circ} \mathrm{F}$, with $1 \mathrm{gram}$ oil/gram catalyst:

These results indicate that the presulfided HRI $5677 \mathrm{Fe}-\mathrm{Mo}$ Macroporous catalyst, on an aqual weight basis, was about as active as the Shell S-317 catalyst. However, the UOP microporous $\mathrm{Ni}$-Mo catalyst had the highest activity of the DMDS presulfided catalysts, while the UOP macroporous $\mathrm{Ni}$-Mo catalysts was of the iowest activity. TNPS presulfiding resulted in higher activity than DMDS presulfiding, whether in gas oil carrier or tetralin carrier (Microautoclave presulfiding), for the Shell S-317 catalyst. 
A consideration in the use of these catalysts is that UOP macroporous catalysts are of considerably lower density than the Shell S-317, or the UOP miniporous catalyst, with a bulk density of $0.38 \mathrm{gms} / \mathrm{cc}$ compared to $0.62 \mathrm{gms} / \mathrm{cc}$. Conseque. $y$, a considerably smaller weight of macroporous catalyst can be charged to the reactors. Additional tests using a is:ver proportion of catalyst were done with the UOP Fe-Mo macroporous catalyst, with the following results for the residual oil conversion in 30 minutes tests at $825^{\circ} \mathrm{F}$ :

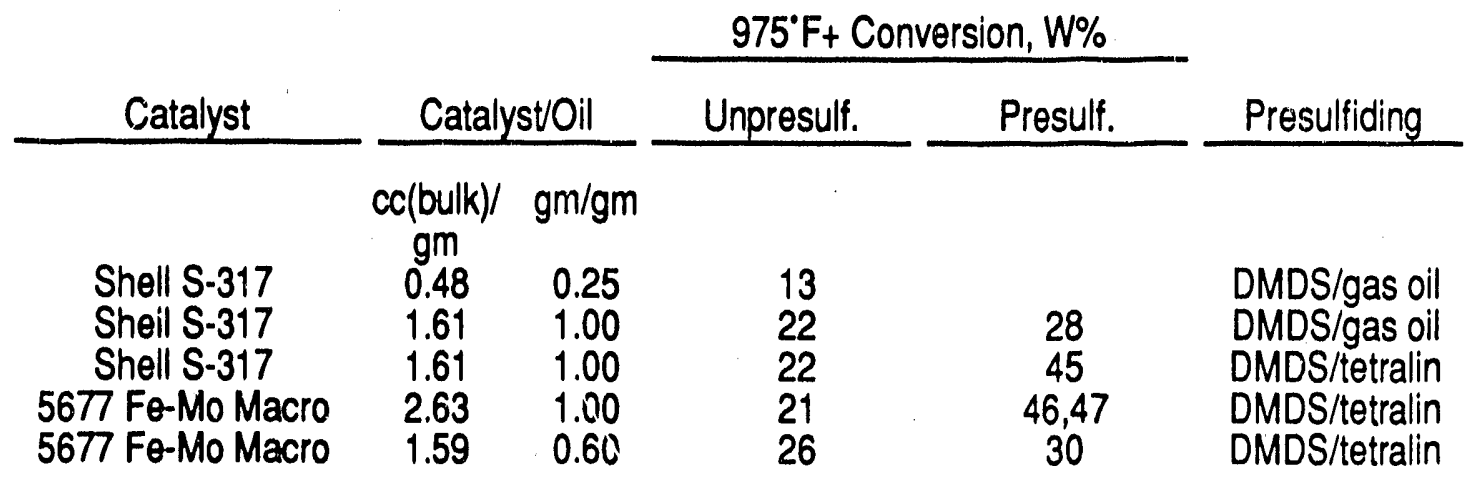

These results with the lower proportion of $\mathrm{Fe}-\mathrm{Mo}$ catalyst are ambiguous. The data for the presulfided catalyst with the lower proportion of catalyst (higher oil/catalyst ratio) did indicate the expected degree of lowered residual oil conversion. However, the results with the lower proportion of unpresulfided Fe-Mo catalyst indicated greater residual oil conversion that had been obtained with the higher proportion of catalyst.

The Iron Oxide Additive (HRI 5664, Southern Clean Fuels) which had indicated regressive residual oil forríation, especially with the addition of elemental sulfur to sulfide the additive, in microautoclave tests reported previously, was tested again with a fresher sample of the CTSL Filtered Liquid being used in these tests. The new tests confirm the regressive residual oil pattern, as follows, summarizing the residual oil contents of the feed and products for the 30 minute tests at $825^{\circ} \mathrm{F}$, with $1 / 1$ additive/oil:

\begin{tabular}{lcc} 
& \multicolumn{2}{c}{$975^{\circ} \mathrm{F}^{+}$Yield, W\% } \\
\cline { 2 - 3 } & \multicolumn{1}{c}{$11 / 89$ Test } & \multicolumn{1}{c}{$1 / 90$ Test } \\
\cline { 2 - 3 } Microautoclave Feed & 32.0 & 25.5 \\
Product (no sulfur added) & 33.6 & 24.9 \\
Product (with 32\% sulfur) & 38.5 & 30.5
\end{tabular}

The reqressive residual oil pattern may be the result of ineffective insitu sulfiding or scavenging of hydrogen from $\mathrm{H}$-donors by the sulfur. 


\section{COALEVALUATIONS}

Black Thunder Mine Coal - A second shipment, HRI 5713 first used in CTSL Bench Unit Run CC-7, gave a coal conversion of $89.8 \%$ in the catalytic microautoclave test, $1.9 \%$ higher than for the earlier shipment, HRI 5630. The coal conversion in the non-catalytic test, $80.3 \%$, was $3.7 \%$ higher than given by the earlier shipment.

Oil Agaiomerated Coal - The cleaned oil agglomerated Illinois coal, containing $4.5 \mathrm{~W} \%$ ash, supplied by Bechtel, and used in CTSL Bench Unit Run CC-6, gave a coal conversion of $93.7 \%$ in the catalytic microautoclave test, $1.5 \%$ lower than had been obtained in a heavy-media cleaned coal that been used in CTSL Bench Unit operations in 1988. The coal conversion in the non-catalytic test, $76.3 \%$, was $5.0 \%$ lower than given by the heavy-media cleaned coal. A sample of the Run-of-Mine Illinois coal that Bechtel had used in their cleaning operation gave a catalytic test coal conversion $0.2 \%$ below that given by the oil-agglomerated coal, and a non-catalytic test conversion $11.9 \%$ higher than obtained with the oil-agglomerated coal. This pattern suggests that a catalytically active component is rejected by coal cleaning operation.

New Mexice Coal - A second shipment of the New Mexico Coal (Gallup, McKinley Mine), which had been used in Co-Processing tests, was evaluated as a candidate for CTSL tests. The coal conversion was $88.4 \%$ in the catalytic microautoclave test, $0.1 \%$ lower than obtained with earlier shipment. The coal conversion was $75.3 \%$ in the non-catalytic microautoclave test, $6.6 \%$ lower than obtained with earlier shipment.

OTISCA Micronized Cleaned Illinois Coal - A sample from a preliminary test by OTISCA on Illinois Coal was evaluated in the microautoclave. This sample was uncharacteristic in that it contained only $1.26 \%$ ash, rather than $3.5 \%$ ash contained in the material ultimately used in the CTSL bench unit. The test sample gave $94.6 \%$ and $80.0 \%$ conversion in the catalytic and non-catalytic microautoclave tests, respectively. These values are $0.6 \%$ and $1.2 \%$ below those obtained with heavy-media cleaned Illinois coal. Further tests are planned with actual OTISCA cleaned material used in the CTSL Bench unit run, and with the Run-of-Mine coal used by OTISCA. 


\section{IASK 3 - BENCH SCALE STUDIES}

\section{RUN 227-63, CC-6}

\section{QBJECTIVES}

A coal cleaned by oil agglomeration was prepared at a DOE contracted facility for evaluation in the CTSL process in comparison to run-of-mine coal.

\section{SCOPE OF WORK}

Run 227-63 (CC-6) completed as scheduled, 13 days of operation with Burning Star Mine Illinois \#6 coal, both with material that had been cleaned by oil agglomeration to reduce the ash content to $4.6 \mathrm{~W} \%$, and run-of-mine uncleaned coal with $15.2 \mathrm{~W} \%$ coal. The run conditions were selected to correspond to those of earlier bench unit CTSL operations with heavy media-cleaned coal with $5.3 \mathrm{~W} \%$ ash, and with electrostatically cleaned coal with $4.9 \mathrm{~W} \%$ ash.

\section{COAL}

The oil agglomerated Burning Star Mine Illinois No. 6 coal used in this run was obtained from Homer City, PA, from a facility operated by the Bechtel Group. The agglomerated material was reported to contain $1.93 \%$ agglomerating asphalt. An assay provided by Bechtel indicated $5.52 \%$ ash, while the samples of feed material to Run 227-63 (CC-6) averaged 4.62. W\% ash content (asphalt-free basis). The sample provided by Bechtel of the run-of-mine material from which the agglomeraied coal had been derived contained $: 5.2 \mathrm{w} \%$ ash.

\section{RUN CONDITIONS}

\begin{tabular}{|c|c|c|c|c|c|}
\hline Cond. & $\begin{array}{c}\text { Days of } \\
\text { Operation }\end{array}$ & Coal Foed & \multicolumn{2}{|c|}{ Temp. } & PFL Recycle Lb/Lb Coal \\
\hline & & & First & Second & \\
\hline $\begin{array}{l}1 \\
2 \\
3\end{array}$ & $\begin{array}{c}1-4 \\
6-9 \\
10-13\end{array}$ & $\begin{array}{l}\text { Agglomerate } \\
\text { Agglomerate } \\
\text { Run-of-Mine }\end{array}$ & $\begin{array}{l}750 \\
750 \\
750\end{array}$ & $\begin{array}{l}800 \\
810 \\
810\end{array}$ & $\begin{array}{l}1.78 \\
1.30 \\
1.15\end{array}$ \\
\hline
\end{tabular}


The coal feed rate for all of these operaricns was about $42 \mathrm{lbs} M A F$ coal/hour $/ \mathrm{tt}^{3}$ catalyst (stage).

Condition 1 corresponds to those of reference operations in the first part of Run 227-37 (I-18) and in Run 227-39 (I-19) with mine washed (10.5 W\% ash), heavy media cleaned ( $5.3 \mathrm{~W} \%$ ash). and electrostatically cleaned $(4.9 \mathrm{~W} \%$ ash) Curning Star Mine coal. The other two conditions correspond to those of the final operations of Run 227-37 (CC-18) and of the demonstration operation for this coal, using heavy niedia cleaned coal, of Run 227-47 (1-27). The catalyst for the current run was fresh Shell S-317, presulfided using TNPS as the sulfiding agent. In the reference operations, this catalyst was used after presulfiding with DMDS as the presulfiding agent.

\section{PERFORMANCE AND RESULTS}

Preliminarily, coal conversions with the agglomerated coal are high, about $1 \%$ higiner than obtained with mine-washed coal, but about $1.5 \%$ lower than obtained with the two other cleaned coais. The run-of-mine coal gave coal conversions about $2 \%$ lower than were obtained with the agglomerated coal. This pattern is consistent with the expectation that the cleaning methods remove some of the less reactive portions of the organic coal along with the ash. However, it would appear that the agglomeration cleanirg method does not reject as large a proportion of such constituents as by the other cleaning methods.

$\mathrm{C}_{4}-975^{\circ} \mathrm{F}$ distillate yields with the agglomerated coal were about $76 \mathrm{~W} \%$ of MAF coal. This yield is about $4 \mathrm{~W} \%$ higher than were obtained with the other cleaned coals, and $6 \mathrm{~W} \%$ higher than with mine-washed coal. A large part of the difference is in lower residual oil yield, and lower residual oil concentrations in Run 227-63 (CC-6) product liquids which were about two-thirds as high as in both reference runs at a commoil catalyst age. The run-of-mine coal operations of Run 227-63(CC-6) had residual nil yields (concentrations) more nearly those observed in the eartier operations, although not quite as high. It is not clear whether this difference is a characteristic of agglomerated coal, or of improved catalyst performance possibly associated with the change in pre-sulfiding procedure with the substitution of TNPS and DMDS. 


\section{TABLE 1}

FEED COAL ANALYSES FOR RUN 227-63 (CC-6)

RUN 227-63 FEED: ILLINOIS NO. 6 BURNING STAR MINE

Feed Designation, HRI No.

227-63 Periods

Moisture, W\%

Ulimate Analysis (W\%. Dry Basis)

Carbon

Hydrogen

Sulfur

Nitrogen

Ash

Oxygen (by difference)
5715

(Run-of-Mine)

$10-12$

2.33

65.12

4.57

3.80

1.33

15.21

9.97
$5716^{* *}$

(Agglomerated)

$1-9$

6.81

Sulfur Forms (W\%. Dry Basis)

Sulfate

0.12

1.84

1.74

74.75

5.23

2.90

1.53

4.62

10.97

Pyrite

Organic

Mineral Analysis of Ash 1 W\%. lanited

Silica, $\mathrm{SiO}_{2}$

Alumina, $\mathrm{Al}_{2} \mathrm{O}_{4}$

Titania, $\mathrm{TiO}_{2}$

Ferric Oxide, $\mathrm{Fe}_{2} \mathrm{O}_{3}$

Lime, $\mathrm{CaO}$

Magnesia, MgO

Potassium Oxide, $\mathrm{K}_{2} \mathrm{O}$

Sodium Oxide, $\mathrm{Na}_{2} \mathrm{O}$

Sulfur Trioxide, $\mathrm{SC}_{3}$

Phosphorous Pentoxide, $\mathrm{P}_{2} \mathrm{O}_{5}$

Undetermined

19.62

0.90

20.52

4.08

1.04

1.76

0.85

1.09

0.31

0.33

.05

0.59

2.23

Microautoclave Results"

Thermai Coal Conversion

Catalytic Coal Conversion

88.2

76.3

93.4

38.40

18.00

0.99

28.02

4.96

1.10

1.70

1.30

4.11

0.31

1.11

- $800^{\circ} \mathrm{F}, 30$ minutes, 2000 psig $\mathrm{H}_{3}$

4/1 (1) Solvent/Coal/Shell(Shell S-317 Catalyst)

Solvent - Wilsonville coal liquefaction distillate product.

** Coal fed also contained $1.9 \mathrm{~W} \%$ agglomeraton asphalt. 


\section{RUN 227-63 OPERATING SUMMARY}

\section{BENCH-SCALE TWO STAGE COAL LIQUEFACTION}

COAL: Illinois No. 6 - Periods 1-9: Oil Agglomerated (HRI-5716)

- Periods 10-12: Run-of-Mine (HRI 5715)

CATALYST: Both Stages: Shell S-317 NiMo 1/32" (HRI 5394)

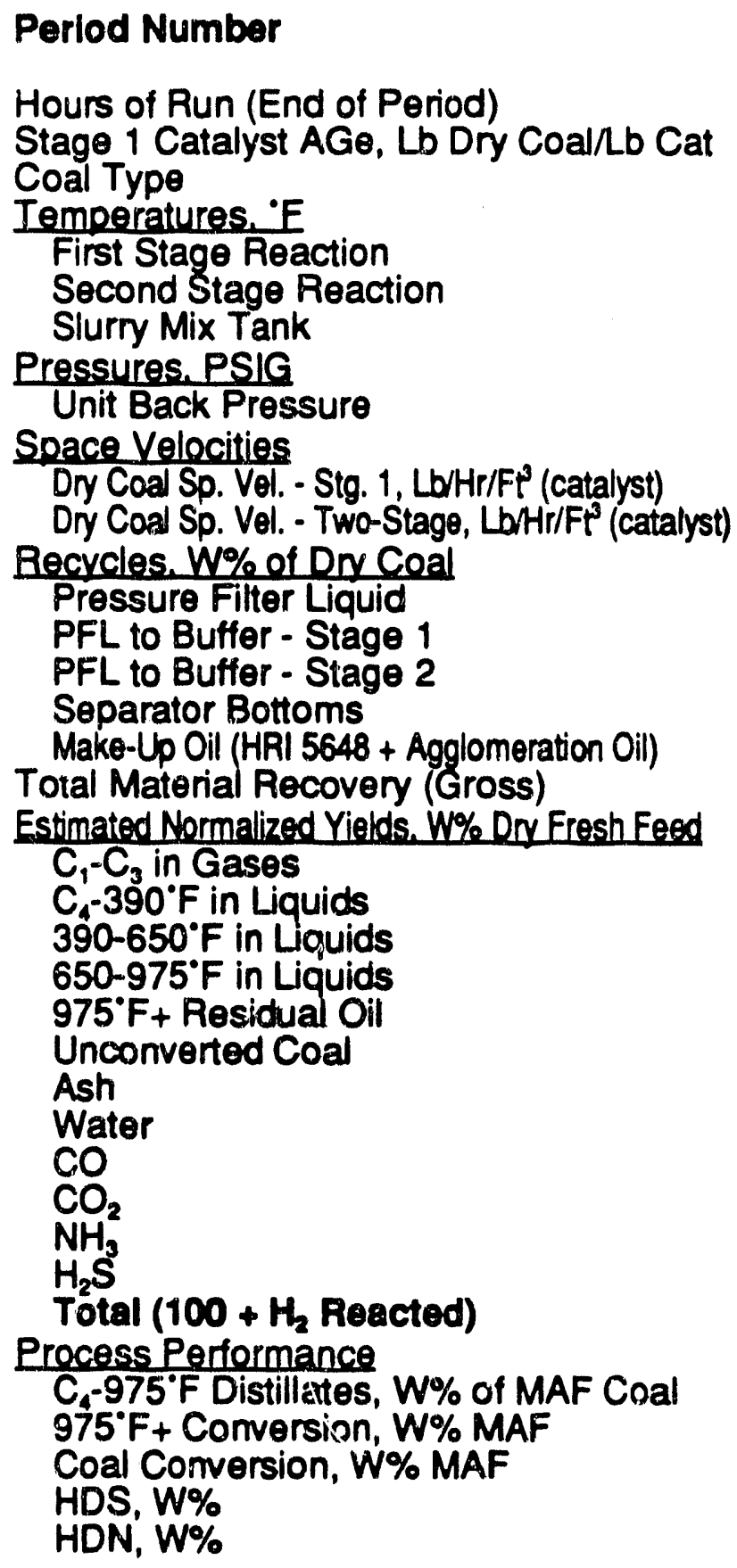

\begin{tabular}{|c|c|c|}
\hline 4 & 9 & 12 \\
\hline $\begin{array}{l}96 . \\
106 . \\
---O i l \text { Agg }\end{array}$ & $\begin{array}{c}213 . \\
233 . \\
\text { arated-..- }\end{array}$ & $\begin{array}{c}285 . \\
319 . \\
\text { R-O-M }\end{array}$ \\
\hline $\begin{array}{l}751 . \\
800 . \\
191 .\end{array}$ & $\begin{array}{l}753 . \\
811 . \\
299 .\end{array}$ & $\begin{array}{l}749 . \\
812 . \\
283 .\end{array}$ \\
\hline 2529. & 2521. & 2524. \\
\hline $\begin{array}{l}44.2 \\
22.1\end{array}$ & $\begin{array}{l}41.1 \\
20.6\end{array}$ & $\begin{array}{l}45.5 \\
22.8\end{array}$ \\
\hline $\begin{array}{c}169.4 \\
4.0 \\
4.3 \\
0.0 \\
1.8 \\
99.45\end{array}$ & $\begin{array}{c}120.4 \\
5.3 \\
5.3 \\
0.0 \\
4.0 \\
96.97\end{array}$ & $\begin{array}{r}103.8 \\
5.2 \\
5.3 \\
0.0 \\
4.6 \\
100.51\end{array}$ \\
\hline $\begin{array}{r}7.57 \\
19.82 \\
33.49 \\
18.19 \\
1.94 \\
5.28 \\
4.62 \\
12.04 \\
0.04 \\
0.04 \\
1.67 \\
2.52 \\
107.23\end{array}$ & $\begin{array}{r}7.28 \\
22.30 \\
33.07 \\
17.32 \\
4.88 \\
4.43 \\
4.62 \\
8.96 \\
0.05 \\
0.04 \\
1.56 \\
2.51 \\
106.99\end{array}$ & $\begin{array}{r}7.57 \\
17.63 \\
29.15 \\
11.57 \\
5.99 \\
5.34 \\
15.21 \\
9.59 \\
0.07 \\
0.04 \\
1.35 \\
2.74 \\
106.25\end{array}$ \\
\hline $\begin{array}{l}75.0 \\
92.4 \\
94.5 \\
81.6 \\
90.1\end{array}$ & $\begin{array}{l}76.2 \\
90.2 \\
95.4 \\
81.3 \\
83.8\end{array}$ & $\begin{array}{l}68.8 \\
86.6 \\
93.7 \\
67.9 \\
83.8\end{array}$ \\
\hline
\end{tabular}




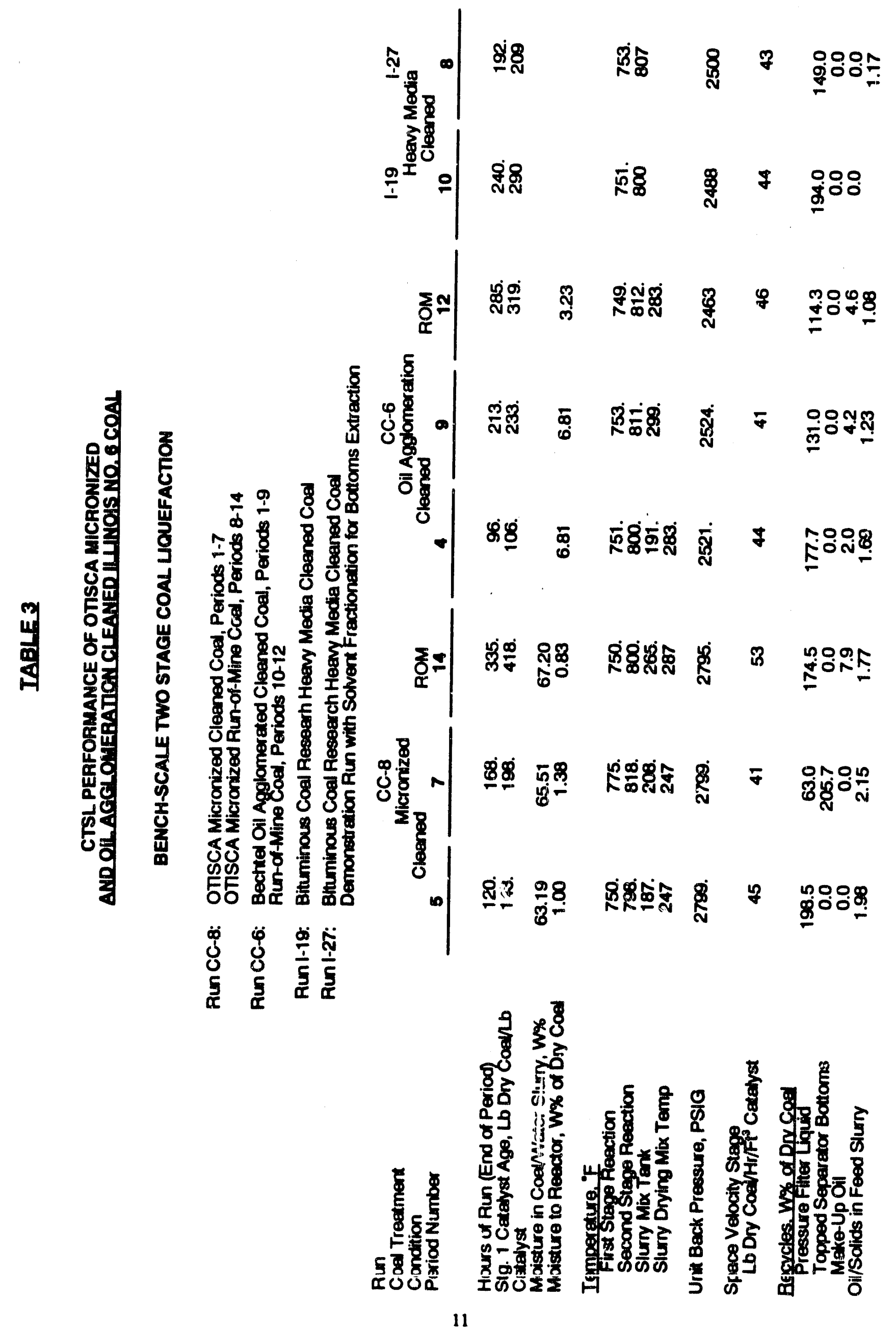




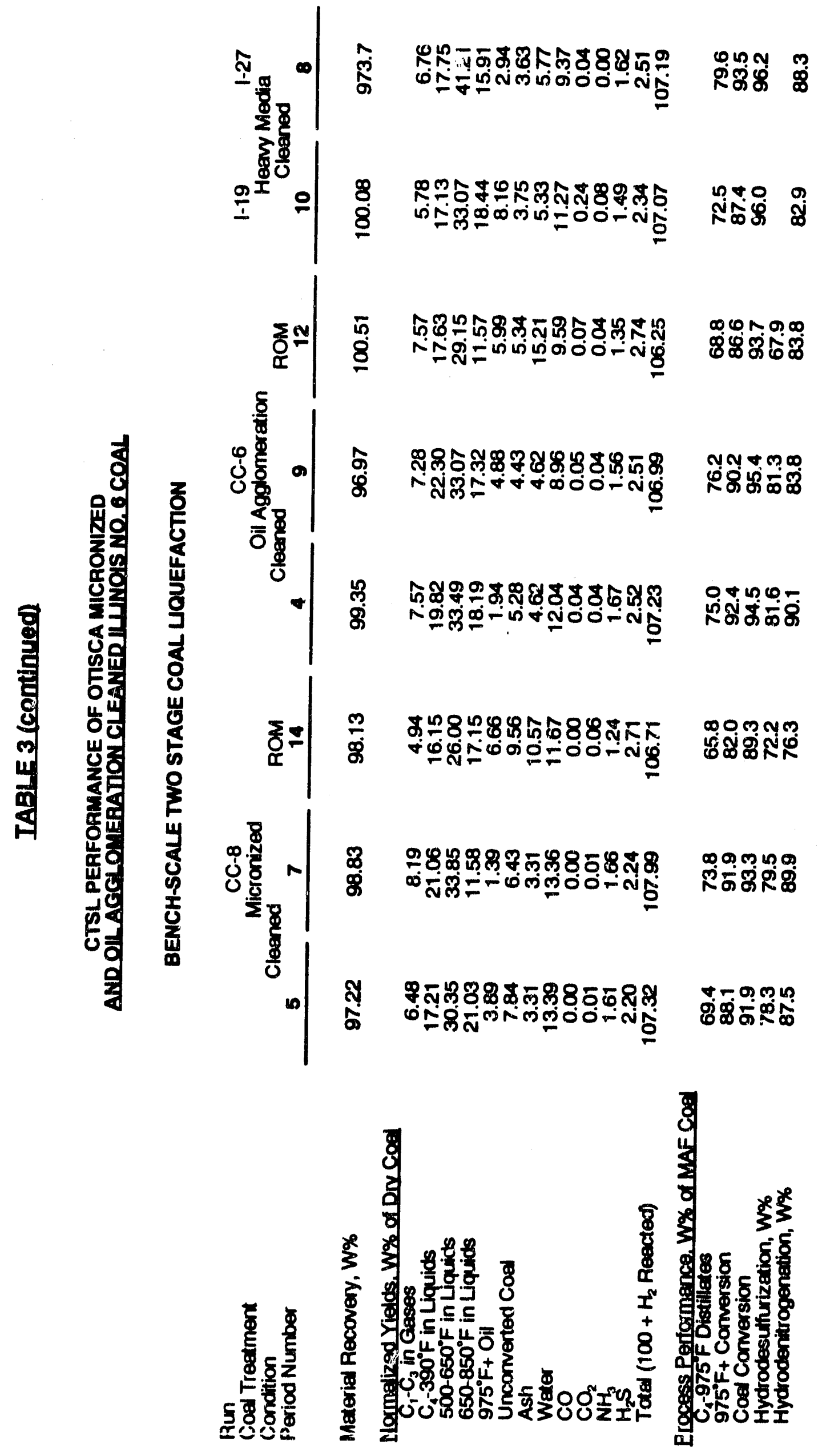




\section{RUN 227-64, CC-7}

\section{OBJECTIVES}

The objective of the run was to study the liquefaction performance in catalytic/thermal (supported catalyst/dispersed catalyst) and thermal/catalytic (dispersed catalyst/supported) configurations using a dispersed iron oxide catalyst and $\mathrm{NiMo}$ aluminum oxide, aged supported catalyst and to compare it with catalytic/catalytic/ configuration.

\section{SCOPE OF WORK}

The run was designed to study the performance of a two-stage liquefaction system where one of the stage contained supported catalyst at low temperature and the other stage was without any supported catalyst and kept at higher temperature. Catalytic activity in the "thermal" stage was provided by a dispersed iron-based additive fed along with the feed coal. Both catalytic-thermal and thermal-catalytic, configuration were studied.

\section{COAL}

The bench run was conducted using Black Thunder mine coal from Wyoming. Two different shipments of coal, HRI 5630 and HRI 5713, were used. The coal analyses are shown in Table 5. The feed coal, screened to obtain -70 mesh size, contained 5-10 W\% moisture after drying at $200^{\circ} \mathrm{F}$ under nitrogen flow.

\section{CATALYST}

The catalyst charged to the unit consisted of $12.5 \mathrm{~W} \%$ fresh Shell 317 (NiMo) catalyst and $87.5 \mathrm{~W} \%$ recovered NiMo catalyst from an earlier bench run (CC-5). The analyses of the catalyst charged for Run 227-61 is shown in Table 6. The catalyst was sulfided in situ by passing a $\mathrm{H}_{2} \mathrm{~S}$ stream continuously along with the start-up oil and holding temperatures at $450^{\circ} \mathrm{F}, 550^{\circ} \mathrm{F}$ for six hours each.

\section{ADDITIVE}

Magnetic pigment, an iron-based additive supplied by Wright Industries (HRI 5723) was used in the test. The analyses are shown in Table 7.

\section{BENCH UNIT}

The bench test was conducted using HRI Bench Unit 227 and was designated as Run 227-64. The products from the reactors were separated using a hot separator and a continuous atmospheric still (CAS) into separator overhead (SOH), atmospheric still overhead (ASOH) and CAS bottoms. The CAS bottoms were pressure filtered in a batch mode into pressure filter liquid (PFL) and pressure filter cake (PFC). PFL was used as recycle solvent and as buffer liquid for the ebullating pumps. 


\section{RUN PLAN}

The run plan for bench test CC-7 is shown in Table 4. The test duration was 20 days plus one 8-hour period. (The letter " $A$ " in the period designation refers to the first third of the period (day).) Magnetic pigment (HRI 5723), an iron-based additive containing $62.91 \mathrm{~W} \% \mathrm{Fe}$, was used throughout the test at $5.2 \mathrm{~W} \%$ of feed. $\mathrm{H}_{2} \mathrm{~S}$ was continuously added at $3.8 \mathrm{~W} \%$ of feed. The space velocity was $67 \mathrm{lb} \mathrm{coal} / \mathrm{hr} / \mathrm{ft}^{3}$ catalyst for the first three conditions and was reduced to $44 \mathrm{lb}$ $\mathrm{coal} / \mathrm{hr} / \mathrm{t}^{3}$ catalyst for the last two conditions. Catalyst was charged only to the first stage at the run start. See table 6 for analysis of catalyst and table 7 for the additive. After the first two conditions, the run was temporarily suspended, the reactors were cocled down, the catalyst was withdrawn from the first stage and charged to the second stage. The reactor containing the catalyst (either to first-or second stage' was maintained at $750^{\circ} \mathrm{F}$. The thermal (dispersed catalyst) reactor was maintained at $825^{\circ} \mathrm{F}$ or at $840^{\circ} \mathrm{F}$, as shown in Table 8.

\section{PERFORMANCE AND RESULTS}

A summary of the process performance is also shown in Table 8 . Product analyses are shown in Table 9.

Coal conversion was calculated from the analyses of the pressure-filter solids under the assumption that the additive is present in the form of $\mathrm{Fe}_{0.85} \mathrm{~S}$. An assumption on the form of additive in PFS is required to assess the loss of inorganic matter that occurs during ashing.

When catalyst was present in the first-stage reactor, coal and residuum conversions at $750 / 825^{\circ} \mathrm{F}$ reactor temperature, were 90.4 and 85.5 (MAF) W\%, respectively. An increase in the second-stage temperature to $840^{\circ} \mathrm{F}$ raised coal conversion to $93.3 \mathrm{~W} \%$ and residuum conversion to $89.0 \mathrm{~W} \%$. The distillate $\left(\mathrm{C}_{4}-975^{\circ} \mathrm{F}\right)$ yield increased by a smaller amount due to increase in $\mathrm{C}_{1}-\mathrm{C}_{3}$ gas yield 9.39 to $11.33 \mathrm{~W} \%$ ).

After Condition 2 the run was suspended and the reactors cooled. The catalyst transferred to the second-stage. The run was restarted and the first-stage, dispersed catalyst, (thermal) temperature raised to $840^{\circ} \mathrm{F}$. Compared to catalytic/thermal operation in Condition 2, Condition 3 (thermal/catalytic) showed lower coal (91.2 versus $93.3 \mathrm{~W} \%$ ) and residuum ( 87.8 versus $89.0 \mathrm{~W} \%$ ) conversions. This indicated that hyc ogenation in the low temperature first stage might be advantageous in improving coal and residuum conversion. However, hydrodenitrogenation (HDN) in the thermal/catalytic case was distinctly better than that in the catalytic/thermal case. There are two possible explanations for this result. In Condition 3 higher coal conversion in the high-temperature first stage and slightly higher second stage temperature $\left(751^{\circ} \mathrm{F}\right)$ might have produced higher nitrogen concentration in the catalytic second stage, thereby increasing the rate of HDN. The other possibility is that the activity of the catalyst might have been partially enhanced due to catalyst washing during the transition from Condition 2 to Condition 3 . The improved product quality in Condition 3 , relative to that in Condition 2, is reflected in higher hydrogen content, higher -API gravity, and lower toluene-insolubles (Table 9). 
The space velocity was decreased by $50 \%$ in Condition 4 . There was no effect on residuum conversion; coal conversion increased only marginally. The distillate yield fell due to very high yield of $C_{1}-C_{3}$ gas (16.26 W\%). In Condition 5 , the first-stage temperature was decreased to $825^{\circ} \mathrm{F}$ from $840^{\circ} \mathrm{F}$. The gas yield decreased to the level obtained in Condition 3. Again, there was no effect on residuum conversion.

Compared to the earlier tests (CC-4) and (CC-1) using catalyst in both stages, the performance in catalytic/thermal mode (Condition 1) was mixed, as shown in Table 10. Residuum conversion was quite similar. Coal conversion was slightly higher in the latter case, probably due to higher slurry hold-up and consequently higher residence time. The product quality was poorer than $\mathrm{CC}-4$ or CC-1.

From comparison of Conditions 2 and 3, it appears that catalytic/thermal (low/high temperature) operation giveis higher conversion than thermal/catalytic (high/low temperature) operation. However, the latter combination gives a slightly better quality product. Increase in the first-stage temperature froin $825^{\circ} \mathrm{F}$ (Condition 3) to $840^{\circ} \mathrm{F}$ (Condition 4 and Condition 5 ) is counter productive.

\section{RESULTS AND CONCLUSIONS, CC-7}

- In catalytic/thermal mode of operation, when the second stage temperature was increased from $825^{\circ} \mathrm{F}$ ic $840^{\circ} \mathrm{F}$, process performance was improved. Although gas yield increased from $9.4 \mathrm{~W} \%$ to $11.3 \mathrm{~W} \%$, the yield of $\mathrm{C}_{4}-975^{\circ} \mathrm{F}$ distillates increased by a small amount.

- Compared to catalytic/thermal mode (Condition 2), thermal/catalytic operation (Condition 3) gave lower coal and residuum conversion. However, HDN was significantly higher.

- In thermal/catalytic mode of operation, increasing first-stage temperature from $825^{\circ} \mathrm{F}$ to $840^{\circ} \mathrm{F}$ did not improve conversions. Gas yield was very high.

- Compared to catalytic/catalytic operation, catalytic/thermal operation showed higher coal conversion but lower $975^{\circ} \mathrm{F}^{+}$conversion and liquid yield. The product quality in the latter case was poorer, higher nitrogen and lower hydrogen contents, lower API gravity, higher amount of preasphaltenes in PFL and consequently higher viscosity.

- Conclude that the catalytic/catalytic mode of operation is preferred to maximize liquid yield and product quality. 
IABLE 4

RUN PLAN - CC-7

CONDITION

PERIODS

NOMINAL CONDITIONS

\section{SPACE VELOCITY RECYCLE RATE \\ PFL/Fresh Foed}

TEMPERATURE. ${ }^{\circ} \mathrm{F}$

Reactor 1

Reactor 2

Slurry Mix Tank

Hot Separator

CAS

BACK PRESSURE, PSIG

Additive Rate,$W \%$ Dry Coal $\mathrm{H}_{2} \mathrm{~S}$ Rate, W\% Dry Coal

\section{1}

1.1

1.1

1.1

1.1

750

825

190

610

525 .

$$
\begin{aligned}
& 750 \\
& 840 \\
& 190 \\
& 610 \\
& 525
\end{aligned}
$$

2500

2500

5.2

5.2

3.8

5.2
3.8

840

825

840

750

190

610

525

750

190

610

610

525

525

2500

2500

2500

5.2

5.2

5.2

3.8

3.8

$\frac{3}{10 A-15 A} \frac{4}{15 B-19 A} \frac{5}{19 B-21 A}$

- Catalyst was charged to first stage; second stage contained no catalyst. After Period 9 unit was cooled and catalyst transferred from first to second stage.

* Magnetic pigment (iron oxide, HRI 5723) was used as additive. 


\section{IABLE 5 \\ EEED COALANALYSES CC-7 \\ BLACK THUNDER MINE (WYOMING COAL)}

HRI NO.

5630

PROXIMATE ANALYSIS, W\%

Moisture

Volatile Matter

7.79

40.76

Fixed Carbon

44.86

Ash

6.59

ULTIMATE ANALYSIS, W\% DRY BASIS

Carbon

Hydrogen

Nitrogen

Sulfur

Ash

ASTM

$\mathrm{SO}_{3}$-Free

68.01

4.71

0.96

0.41

4.75

4.75

0.91

6.60

0.46

5.74

7.66

6.65

MINERAL ANALYSIS, W\% ASH

Silica

Alumina

34.61

Titanium Oxide

16.98

Iron Oxide

1.30

Calcium Oxide

Magnesium Oxide

6.94

Potassium Oxide

21.74

Sodium Oxide

4.40

Sulfur Trioxide

0.35

Phosphorous Pentoxide

0.97

10.74

Strontium Oxide

1.01

Barium Oxide

0.29

Manganese Oxide

0.37

Undetermined

0.00

0.30

MACERAL ANALYSIS, W\%

Vitrinite

73.4

Exinite

3.6

Semifusinite

12.5

Micrinite

8.5

Fusinite

2.0 


\section{F.LEMENTAL ANALYSIS}

Carbon, W\%

Hydrogen, $W \%$

0.89

Nitrogen, $W \%$

0.18

Sulfur, $W \%$

Molybdenum, W\%

9.10

Nickel, W \%

1.93

Iron, $W \%$

0.58

Titanium, $W \%$

0.03

Calcium, $W \%$

0.09

Sodium, $W \%$

0.43

Average Age, Lb Coal/Lb Catalyst

468 


\section{TABLEI}

HRINO.

TYPE

Element of Analysis

Carbon, W\%

Hydrogen, $W \%$

Nitrogen, $W \%$

Sulfur, $W \%$

Water, W \%

Ash, W\%
5689/5723*

MAGNETIC PIGMENT

(Oxide)

0.14

0.00

0.00

0.003

0.02

102.75

\section{Ash Analysis (W \% Ash)}

Silicon Dioxide

0.93

Aluminum Oxide

0.07

Titanium Oxide

0.20

Iron Oxide

98.36

Calcium Oxide

0.05

Magnesium Oxide

0.22

0.02

0.07

0.07

0.03

0.02

Undetermined
0.05

25.14

70.42 


\section{TABLE 8}

SUMMARY OF FEESULTS - CC-7

CONDITION

PERIOD

TEMPERATURE. ${ }^{\circ} F$

First Stage

Second Stage

SPACE VELOCII $Y$

Lbs Coal/Hr/Ft Catalyst

CATALYST AGE (LB COAL/LB

CATALYST)

RECYCLE RATE (PFL/MAKE-UP), W \% 114.2 COAL

ADDITIVE, W \% DRY COAL

$\mathrm{H}_{2} \mathrm{~S}, \mathrm{~W} \%$ COAL

\section{YIELDS (\% OF DRY COAL)}

$\mathrm{C}_{1}-\mathrm{C}_{3}$
$\mathrm{C}_{1}-390^{\circ} \mathrm{F}$
$390-500^{\circ} \mathrm{F}$
$500-650^{\circ} \mathrm{F}$
$650-975^{\circ} \mathrm{F}$
$975^{\circ} \mathrm{F}^{+}$Liquid
Unconverted Coal + Mineral Ash
Water
$\mathrm{CO}+\mathrm{CO}_{2}$
$\mathrm{NH}_{3}$
$\mathrm{H}_{2} \mathrm{~S}^{\prime}$
OTAL (100+

PROCESS PERFORMANCE

Coal Conversion, $W \%$ MAF

$975^{\circ} \mathrm{F}^{+}$Conversion, $\mathrm{W} \%$ MAF

$C_{4}-975^{\circ} \mathrm{F}$ Yield, W\% MAF

Hydrodenitrogenation

4.5

\begin{tabular}{|c|c|c|c|c|}
\hline 1 & 2 & 3 & 4 & 5 \\
\hline $4 / 5$ & 8 & $13 / 14$ & $17 / 18$ & 20 \\
\hline $\begin{array}{l}74 \beta \\
825\end{array}$ & $\begin{array}{l}750 \\
838\end{array}$ & $\begin{array}{l}838 \\
757\end{array}$ & $\begin{array}{l}839 \\
751\end{array}$ & $\begin{array}{l}825 \\
750\end{array}$ \\
\hline
\end{tabular}

$\begin{array}{lllll}66.9 & 65.6 & 68.4 & 45.8 & 43.8\end{array}$

$\begin{array}{lllll}658 & 807 & 975 & 1101 & 1170\end{array}$

$\begin{array}{lllll}114.2 & 115.0 & 115.4 & 115.1 & 120.0\end{array}$

$5.5 \quad 5.3$

5.5

5.4

5.7

4.7

4.3

5.0

5.4

$\begin{array}{rrrrr}9.39 & 11.33 & 13.51 & 16.26 & 13.17 \\ 13.86 & 16.46 & 20.05 & 22.68 & 21.91 \\ 4.52 & 10.23 & 11.54 & 12.47 & 11.71 \\ 16.00 & 15.66 & 14.91 & 17.76 & 15.65 \\ 15.71 & 14.71 & 7.72 & -0.77 & 5.85 \\ 4.59 & 4.07 & 3.16 & 4.46 & 3.25 \\ 15.73 & 12.79 & 15.77 & 14.56 & 16.09 \\ 17.85 & 17.43 & 17.07 & 17.23 & 17.33 \\ 4.16 & 4.94 & 4.28 & 3.48 & 3.42 \\ 0.67 & 0.64 & 0.78 & 0.77 & 0.60 \\ -1.13 & -1.37 & -1.57 & -1.07 & -1.25 \\ 106.34 & 107.01 & 107.21 & 107.78 & 107.73\end{array}$

$\begin{array}{lllll}90.4 & 93.3 & 91.2 & 92.4 & 90.8 \\ 85.5 & 89.0 & 87.8 & 87.7 & 87.4 \\ 58.5 & 60.5 & 58.1 & 55.9 & 59.0 \\ 57.4 & 55.1 & 71.1 & 69.0 & 53.9\end{array}$

1 Negative $\mathrm{H}_{2} \mathrm{~S}$ yields indicate net $\mathrm{H}_{2} \mathrm{~S}$ comsumption due to reaction with the additive. 


\section{TABLEQ}

ANALYSES OF PRODUCTS - CC-7

CONDITION

PERIOD

CATALYST AGE (LB COALLB CATALYST

SEPARATOR OVERHEAD

Volume Average BP, $F$

-API Gravity

Watson Charactertization Factor

Carbon, $W \%$

Hydrogen, $W \%$

Nitrogen, $W \%$

Sulfur, $W \%$

ATMOSPHERIC OVERHEAD

Volume Average BP, $F$

-API Gravity

Watson Characterization Factor

Carbon, $W \%$

Hydrogen, $W \%$

Nitrogen, $W \%$

Sulfur, $w \%$

CALCULATED CAS BOTIOMS

IBP-975 $\mathrm{F}, W \%$

$975^{\circ} \mathrm{F}^{+}$Toluene Soluble Oil

$975^{\circ} \mathrm{F}^{+}$Toluene Insoluble Oil

IOM

Ash*

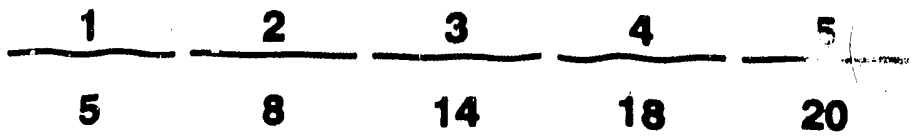

$\begin{array}{lllll}679 & 807 & 996 & 1115 & 1170\end{array}$

$\begin{array}{rrrrr}488 & 486 & 451 & 430 & 436 \\ 24.7 & 24.6 & 28.7 & 30.3 & 30.1 \\ 10.67 & 10.66 & 10.82 & 10.82 & 10.83 \\ 85.83 & 86.28 & 87.13 & 87.02 & 87.11 \\ 11.54 & 1 . .61 & 12.04 & 12.27 & 12.35 \\ 0.40 & 0.43 & 0.29 & 0.33 & 0.47 \\ 0.05 & 0.04 & 0.07 & 0.04 & 0.04\end{array}$

$\begin{array}{rrrrr}470 & 469 & 466 & 481 & 475 \\ 21.7 & 20.8 & 23.4 & 22.2 & 22.9 \\ 10.51 & 10.47 & 10.63 & 10.60 & 10.64 \\ 85.44 & 84.96 & 86.40 & 87.38 & 86.66 \\ 11.81 & 11.17 & 11.54 & 11.42 & 11.63 \\ 0.46 & 0.53 & 0.34 & 0.43 & 0.46 \\ 0.03 & 0.03 & 0.03 & 0.03 & 0.06\end{array}$

$\begin{array}{rrrrr}60.27 & 60.04 & 63.63 & 62.04 & 63.35 \\ 25.29 & 20.51 & 20.49 & 21.61 & 21.49 \\ 12.11 & 7.98 & 3.24 & 3.30 & 3.08 \\ 6.27 & 3.84 & 5.38 & 4.74 & 5.25 \\ 6.96 & 5.94 & 7.25 & 8.32 & 6.84\end{array}$

- On an $\mathrm{SO}_{3}$-Free basis, includes additives. 
Run No.

Condition

Period

Catalyst Age (Lb Coal/Lb Catalyst)

First Stage

Second Stage

Space Velocity ( $\mathrm{Lb} / \mathrm{Hr} / \mathrm{Ft}^{3}$ Catalyst)

Temperature. ${ }^{\circ} \mathrm{F}$

First Stage

Second Stage

Additive Rate, W\%

Coal Conversion, W\% MAF

S75 ${ }^{\circ} \mathrm{F}+$ Conversion W\% MAF

$\mathrm{C}_{4}-975^{\circ} \mathrm{F}$ Yield, W\% MAF

HDN, W\%

$\mathrm{H}_{2}$ Consun tion, W\%

Properties, $500-650^{\circ} \mathrm{F}$ Product

Hydrogen, WT\%

Nitrogen, WT\%

Sulfur, WT\%
CC. 4

$12 / 13$

CC-7

$4 / 5$

CC-1

6

22

717

1088

68.9

658

660

660

66.9

68

751

825

5.2

748

825

5.5

750

825

0

87.5

88.1

64.6

76.9

8.1

90.4

85.5

58.5

57.4

6.3

87.3

82.7

59.8

65.4

7.2

11.1

0.2

9.33

0.51

0.02
10.64

0.30

0.01 


\section{RUN CC-8 $(227-65,66)$ OTISCA CLEANED COAL}

\section{OBJECTIVES AND SCOPE OF WORK}

The primary purpose of this operation was to evaluate the liquefaction potential of a tine, micronized cleaned coal with ash levels approaching $2 \%$ on a dry coal basis.

The coal delivered as a $35 \%$ slurry in water was mixed with recycle oil and dried prior to entering the ebullated bed reactor. It was thus necessary to develop drying and handling procedures for this coal/water slurry.

\section{BACKGROUND}

Run CC-8 - First attempted as Run 227-65 and finally completed as Run 227-66, evaluated Illinois \#6 coal reduced to $3.6 \mathrm{~W} \%$ ash content by OTISCA Industries using their proprietary process. The cleaned coal has been provided, as generated, in a water slurry containing about $35 \%$ solids.

A process had to be developed which provided a pumpable feed slurry without excessive water inclusion into the high pressure process. Preliminary testing indicated a possible difficulty in using very low ratios of recycle oil to coal, possibly due to snhancerd swelling cf the extremely fine coal ( 5 micror: median diameter). A conservative value of $2 / 1$ recycle oil/dry coal was selected for use in the balance of the Bench Unit test operations, with relatively brief operations to 'Je attempted with lower oil/coal rations. The run plan included demonstration of the process performance of the coal at usual CTSL operating conditions using solids-free filtered recycle oil, and tests with a high proportion of unfiltered solids-containing recycie oil to demonstrate the reduced recycle oil clarification requirements that might be accomplished with such cleaned coals. The run plan also included operations with run-of-mine lllinois coal similarly micronized in water slurry (the feed to the OTISCA cleaning operation).

\section{SLURRY DRYING PROCEDURE}

The coal/water slurry mixed with recycled oil was dried in the slurry drying system, which had been installed for thermal pretreatment in Run 227-62. Eight hour feed batches of the coal/water slurry along with recycled filtered product (and unfiltered product) was heated for approximately six hours (until almost all of the water was removed) and then pumped to the feed slurry holder for the high pressure CTSL equipment. A total sparging nitrogen flow was used equal to the water content to be removed. The quantity of water recovered from the drier was determined, as woll as the water content of the dried slurry. The entire inventory of dried slurry was transferred at the end of drying cycle for feed to the high pressure equipment during the following eight-hour interval. 
For Run 227-65 the temperature in the drying cycie was limited to $210^{\circ} \mathrm{F}$. While about $85 \%$ of the water was removed in the operation, the water still remaining in the slurry was very high, corresponding to $20-35 \%$ of the dry coal fed. In run 227-66, with a temperature limit of $275^{\circ} F$, drying was more complete with this water content at about $1-2 \mathrm{~W} \%$ of the dry coal fed.

Since pretesting indicated possible pumping difficulties with low ratios of oil to coal, operations for the first two days was with a higher than target recycle oil to coal ratios. This involved successive 16 hour operation with unit feed of $4 / 1$, $3 / 1$ and 2.5/1 recycle oil/dry coal, before the target ratio of $2 / 1$ used in the third day. The operating experience of Run 227-65 permitted more rapid arrival at the target oil/coal ratio after 32 hours of coal operations in Run 227-66.

\section{PRELIMINARY WATER SLURRY DRYING TESTS}

Prior to the delivery of the OTISCA cleaned Illinois coal that was used in Run CC-8, preliminary small scale tests on slurry preparation were carried out using a Kentucky coal/water slurry provided by OTISCA. These tests indicated that preparation of pumpable slurries with less than 2 parts oil to 1 part of dry coal was unlikely. Drying of the coal/water/oil mixture at atmospheric pressure would require temperatures over $300^{\circ} \mathrm{F}$ for removal of all the water, with the development of very plastic mixture, virtually unpumpable. Under moderate vacuum, a high proportion of drying was attained at about $200^{\circ} \mathrm{F}$ and the resulting water-free coal/oil mixture was sufficiently fluid to permit pumping to the high pressure system. This behavior led to the use in the bench unit drying apparatus of a nitrogen sparge at a rate equal to the total amount of water to be vaporized.

These sinall scale tests indicated the desirability of keeping temperature of the slurry drying/preparation as low as feasible, so that this temperature was kept below $220^{\circ} \mathrm{F}$ during Run 227-65. However, a considerable amount of water was sill unvaporized, corresponding to as much as $35 \%$ of the dry coal fed. This factor may have contributed to the poor operability of Run 227-65.

Further small scale tests after Run 227-65, now with the Illinois coal water slurry indicated that the slurry preparation temperature could be raised somewhat while obtaining pumpable dried coal/oil slurries. In Run 227-66, drying temperatures up to $275^{\circ} \mathrm{F}$ were used, with increased water removal, and no pumping difficulties, at least with the $2 / 1$ oil/coal slurries.

\section{RUN 227-65}

Operations with coal feed in Run 227-65 started on March 8, 1990 and proceeded for three days successfully completing the program of reducing the proportion of recycled slurrying oil to target value of two lbs/lb dry coal while 
maintaining the feed of slurry to the high pressure system. In the third day, a persistent increase in pressure drop across the first stage reactor developed, reaching 200 psi, with apparent loss of the ebullating internal recycle oil flow around that reactor and a plugging in this recycle oil line. The coal feed was stopped at the end of the third day for inspection of the unit. The blockage was found to be due to catalyst.

While the almost continuous change in conditions (oil/coal ratio) for these operations do not allow a complete material balance evaluation of the operations of this run, some significant factors are apparent. The coal conversion reached a value of $94.5 \%$ in the third day of operations, with the lowest oil/coal ratio. While 1-1.5\% lower than obtained with other cleaned Illinois coals, this difference might be ascribed to the high proportion of clean oil recycle used in this run. Collected gas yield, $6.8 \%$ of dry coal, was at the high end of the range of gas yields with other cleaned and uncleaned Illinois coals at the coal rate and reactor temperatures used in this run. The concentration of residual oil in filtered product oil (recycle solvent) was about the same as holding at the same stage in comparable operations with other cleaned Illinois coals. It appears that the operating results with the OTISCA cleaned Illinois coal would be comparable to those with other cleaned Illinois coals, although if high proportions of solids-free recycle solvent are indeed nesded the coal conversions might be slightly lower with the micronized coal.

Despite the relatively small particle size of the coal fed, and presumably of the solids produced, there were no difficulties in filtering the product slurry to obtain the solids-free recycle solvent. The filtration rates were comparable to those of the other CTSL operations, and the filtrate contained minimal amounts of mineral matter.

\section{RUN 227-66 (CC-8)}

On March 20, testing of the OTISCA cleaned Illinois coal as Run CC-8 was resumed in Run 227-66 with charges of fresh catalyst to both stages. Twelve days of operations have been completed at the end of the report period, and this evaluation is scheduled to be completed on April 4.

The major difference of Run 227-66 from Run 227-65 was the use of higher temperature, up to $275^{\circ} \mathrm{F}$, in slurry preparation operation. Consequently, water remaining in the feed slurry to the high pressure system has been reduced to about $1.2 \%$ of the dry coal content. There have been no operating problems in feed slurry preparation or in the reaction system when using an oil/dry coal ratio of 1.67 or higher. However, when an attempt was made to use an oil/coal ratio of 1.17 (a ratio used in other coal evaluations) circulation could not be maintained in the slurry preparation system, and dilution with oil to the more normal oil/coal ratio was necessary. Results will be included in the next quarterly report. 


\section{EEED COALANALYSES FORRUN 227-66 (CC-8)}

RUN 227-66 FEED: OTISCA PROCESSED ILLINOIS NO. 6 COAL

Feed Designation, HRI No.

Typo

Feed for Periods

Moisture Content

As Received Slurry, W\%

Analyzed Sarnple, W\%

Proximate Analysis. $W \%$

Moisture, W\%

Volatile Matter, (MAF Basis)

Fixed Carbon (MAF Basis)

Ultimate Analysis $M \%$. Dry Basis)

Carbon

Hydrogen

Sulfur

Nitrogen

Chlorine

Ash

Oxygen (by difference)

Oxygen (Unterzuacher)

$\frac{5738}{\substack{\text { Cleaned } \\ 1-7}} \frac{5739}{\substack{\text { Uncleaned } \\ 8-15}}$

67.22

1.25

67.01

1.61

61.86

44.78

55.22

43.91

56.09

75.87

5.17

2.65

1.52

0.04

3.46

11.33

13.24

69.27

4.53

3.53

1.34

0.07

10.57

10.69

16.02

Sulfur Forms 1 \%\%, Dry Basis)

Sulfate

Pyrite

0.07

0.60

2.07

0.11

1.28

1.97

13124

12303

13594

13757

Mineral Analysis of Ash W\%, Ionited Silica $\mathrm{SiO}_{2}$

Alumina, $\mathrm{AL}_{2} \mathrm{O}_{3}$

Titania, $\mathrm{TiO}_{2}$

Ferric Oxide, $\mathrm{Fe}_{2} \mathrm{O}_{3}$

Lime, CaO

Magnesia, MgO

Potassium Oxide, $\mathrm{K}_{2} \mathrm{O}$

Sodium Oxide, $\mathrm{NaO}^{\circ}$

Sulfur Trioxide, $\mathrm{SO}_{3}$

Phosphorous Pentoxide, $\mathrm{P}_{2} \mathrm{O}_{5}$

Strontium Oxide, SrO

Barium Oxide, BaO

Manganese Oxide, Mn304

Undetermined
33.50

16.50

1.90

33.16

5.98

1.20

1.30

0.44

5.20

0.10

0.76
44.57

19.79

0.78

22.40

5.00

0.88

1.80

0.42

3.43

0.70

0.03

0.05

0.01

Continued..... 


\section{FEED COALANALYSES FORRUN 227-66 (CC-8)}

RUN 227-66 FEED: OTISCA PROCESSED ILLINOIS NO. 6 COAL

Feed Designation, HRI No.

Typo

Foed for Periods

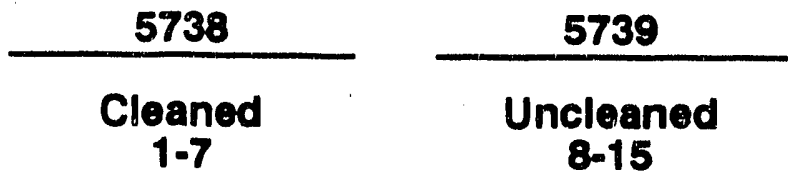

Particle Size Distribution, W\%

$>11.5$ microns

4.9

11.5

10.5

9.5

8.5

7.5

6.5

5.5

4.5

3.5

2.5

1.5

0.5

3.7

1.6

9.7

1.8

2.4

5.2

5.2

3.3

4.8

4.7

7.8

10.3

11.3

12.7

14.0

17.2

4.8

6.6

8.85

8.35

9.9

11.5

12.85

13.35

3.85

Microauteclave Results*

Thermal Coal Conversion

85.7

90.0

Catalytic Coal Conversion

93.4

93.3

- 1989 tests $-800^{\circ} \mathrm{F}, 30$ minutes, 2000 psig $\mathrm{H}_{2}$ 4/1 (1) Solvent/Coal/Shell(Shell S-317 Catalyst)

Solvent - Wilsonville coal liquefaction distillate product. 


\section{TASK 4 - TECHINICAL ASSESSMENT}

A comparison of the economics of processing Wyoming sub-bituminous coal at two space velocities in the same plant, except with larger reactors for the high space velocity case, was completed in this period. Costs were based on a 1988 plant design and also as shown in Table 13, "Economic Basis", the rate of return is increased from 12 to $15.6 \%$ as a result of the $50 \%$ increase in space velocity. 


\section{TABLE 12}

\section{ECONOMICS OF CTSLPROCESSING OF WYOMING SUB-BITUMINOUS COAL}

\section{ECONOMIC BASIS}

\begin{tabular}{lr} 
Type of Financing, \% Equity & 100 \\
Construction Period, Years & 4 \\
& \\
Draw-Down \% & \\
\hline First Year & 5 \\
Second Year & 25 \\
Third Year & 45 \\
Fourth Year & 25
\end{tabular}

Escalation Rate During Construction $\quad 5$

Deprociation Period, Years 25

Depreciation Type Straight Line

Capacity Factor \%

First Year $\quad 65$

Second Year $\quad 80$

Thereafter 100

Inflation Rate, \% 4

Income Tax Rate, \% 33

Senice Factor, \% 90

Product Pricing vs Crude Oil $\quad 1.3$

Crude Oil Price \$1/Bb| DOE Forecast

$\begin{array}{ll}1990 & 20 \\ 1995 & 26 \\ 2000 & 33\end{array}$




\section{TABLE 13}

\section{CTSLPROCESSING OF WYOMING SUB-BITUMINOUS COAL}

\section{ECONOMIC ANALYSIS}

Plant Size, Ton/Day

Space Velocity, Lbs/ $\mathrm{Hr} / \mathrm{Ft}^{3}$ Catalyst

\section{Product Rate, B/Day}

Gasoline Jet/Diesel Fuel

Gross Revenue, MM\$YYR

Net Income, MM\$YYR

IRR
8,000

45

11,450

20,180

17,179

5,245

12.0
12,000

67

17,175

30,270

25,686

8,905

15.6 


\section{TASK 6}

\section{ADMINISTRATION, REPORTING AND SAMPLE HANDLING}

An updated schedule of Bench and PDU Scale operations is shown on the attached page. This schedule includes an additional operation on OTISCA coal and shows a break in Bench Testing from May through August.

Samples for analysis by Penn State and Consolidation Coal are in the selection stage and will be shipped in the next period. 


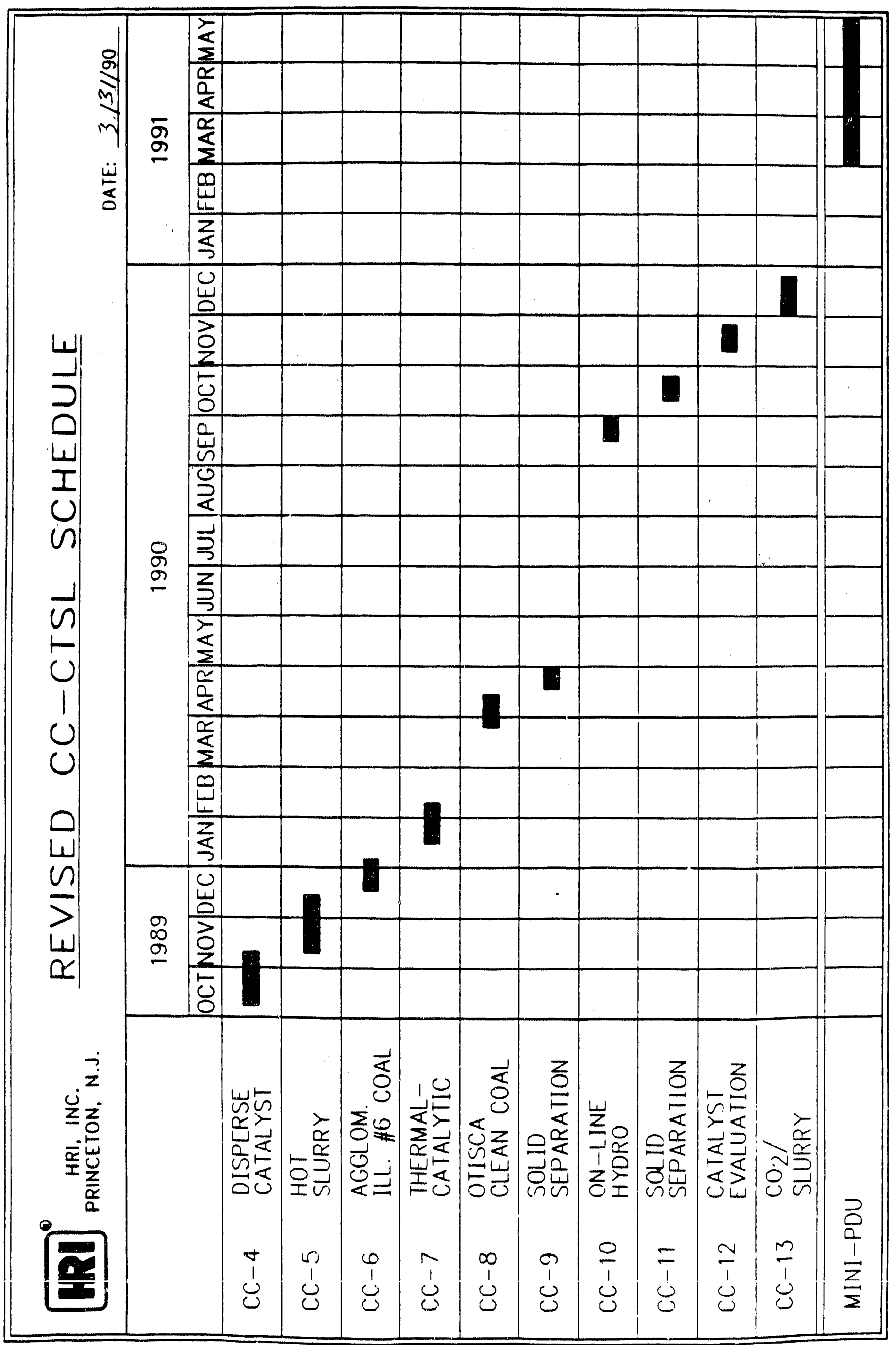



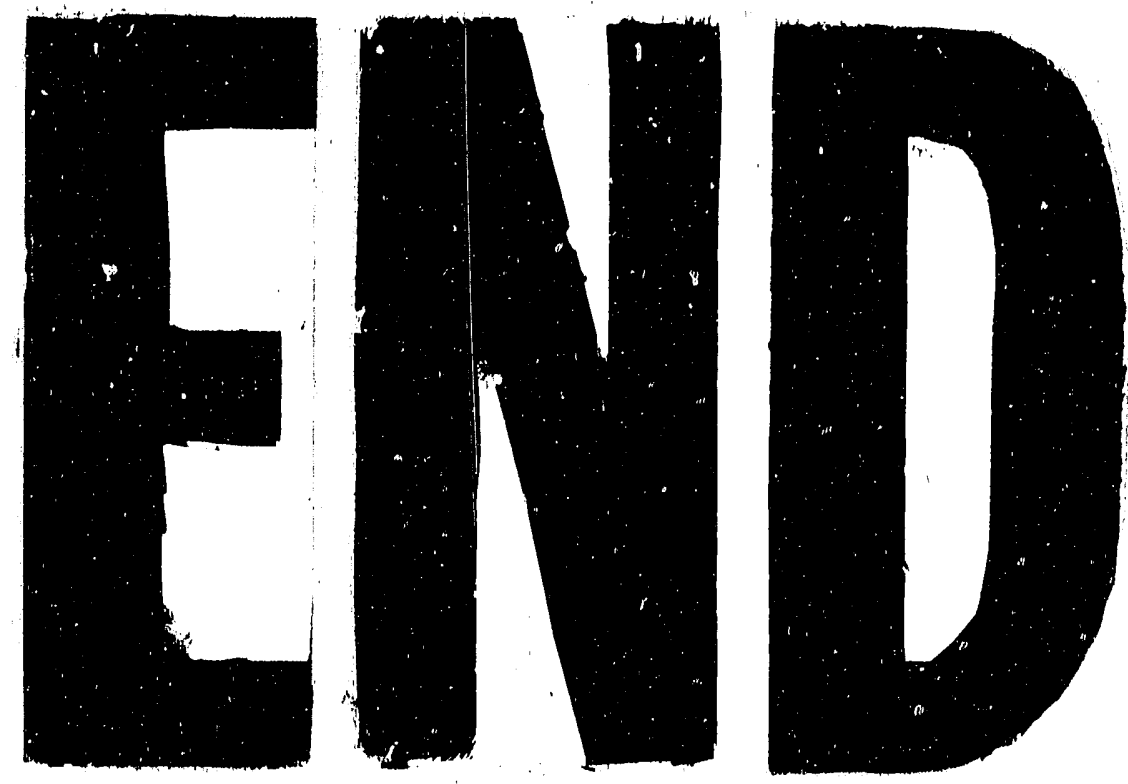

4
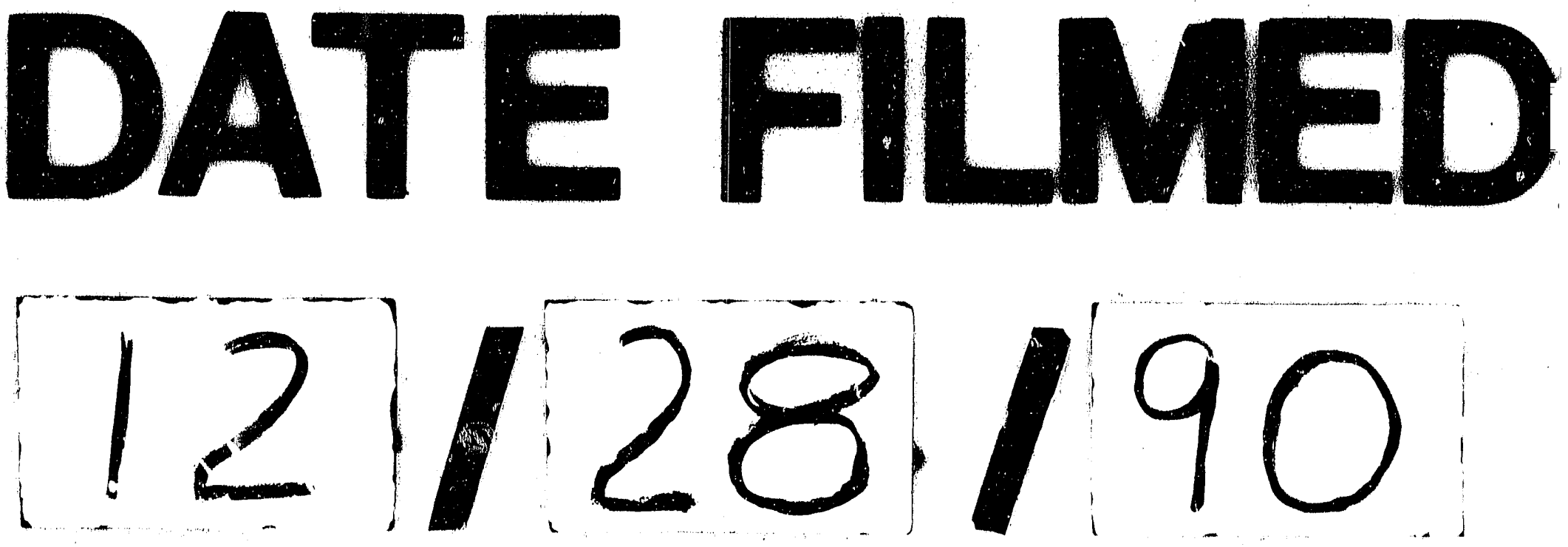
